\title{
Coconut Leaf Vermiwash as a Component of Organic Farming for Sustaining Soil Health and Fertility
}

\author{
Murali Gopal*, Alka Gupta and George V. Thomas
}

\begin{abstract}
Vermiwash, produced from actively vermicomposting substrates of coconut leaf + cowdung by the action of Eudrilus sp., has an alkaline $\mathrm{pH}$, contains major and minor nutrients, growth hormones, humic acid and plant beneficial bacteria. Application of appropriately diluted coconut leaf vermiwash has shown to increase germination and seedling vigour index of cow pea and paddy seeds in laboratory bioassays. Field trials with cowpea, maize and bhendi (okra) in CPCRI farm showed its capacity to increase biomass and yield of the crops accompanied by enhanced soil microbial activities. Application of the vermiwash in red sandy loam soil produced an increase of $36 \%$ of fresh biomass weight, nodule numbers and $43 \%$ nodule fresh weight in cowpea at 1:10 dilution compared to control. In maize, increase in cob yield by 5-10\%, fresh cob weight increase of $29-64 \%$ and in bhendi 22 to $33 \%$ increase in yield were recorded when vermiwash was applied at 1:5 dilution. To validate these results, field trials were taken up in farmers' plots at Majal and Edneer area in Kasaragod. Bitter gourd and cowpea crops were taken up at Majal while amaranthus, cowpea and green chillies at Edneer. The soil type was sandy loam at Majal and lateritic at Edneer. Vermiwash produced at CPCRI was used as treatment along with farmers' practice as control. The mode of application of vermiwash, dilution rates and intervals of application were carried out by the farmers as per recommendations. Observations on yield of the crops in vermiwash applied plots were recorded by the farmers. A yield of $75 \mathrm{~kg}$ cowpea and $200 \mathrm{~kg}$ bitter gourd at Majal; $55 \mathrm{~kg}$ amaranthus, $155 \mathrm{~kg}$ cowpea and 10kg dried chilli at Edneer plot were recorded from vermiwash applied plots.

In both the places, observations indicated that application of vermiwash resulted in yield of crops on par or slightly lower than the plots that received regular fertilizer inputs as per farmers' practice. However, in vermiwash treated plots, the farmers listed many other important points viz. healthy plant and root hair growth, lesser pest and disease damage, larger leaf size and deep leaf colour, longer ability of plants to stay without wilting in field as well as longer time of remaining fresh in case of amaranthus after harvesting, etc. The soil analysis also revealed that application of vermiwash in both types of soils increased the bacterial, fungal, actinomycetes, free-living nitrogen fixing, phosphate solubilzing and fluorescent pseudomonad population, and dehydrogenase, urease and phosphatase enzyme activities when compared to fertilizer treated plots. This clearly established the fact that vermiwash enhanced the soil fertility status for production of quality yield of agronomic and horticulture crops.
\end{abstract}

Keywords: coconut, microflora, organic farming, soil health, vermiwash

\footnotetext{
* Central Plantation Crops Research Institute, Kudlu P.O., Kasaragod - 671 124, Kerala, India.

Tel: +91-4994-232894 ext. 225

Email: mgcpcri@yahoo.co.in
} 


\section{Introduction}

Vermiwash is a by-product obtained from vermicompost production technology that can be used as a liquid organic fertilizer for improving crop growth and yield (Ismail, 1997). Vermiwash production can be done basically by two methods. One method involves soaking soil + cow dung + earthworms substrate in excess water in plastic tub and siphoning the wash periodically from the bottom of the tub while another one involves releasing the earthworms in lukewarm water and agitating them gently so as to shock them to secrete higher amount of body fluids and mucus (Kale, 1988). This liquid organic fertilizer is rich in nutrients and plant growth hormones and its application has been reported to stimulate anthurium, increase soil nutrient status and yield of paddy, biological productivity of marigold, Aloe vera, fruit quality of tomatoes, yield of spinach, onion and potato and cowpea.

\section{Materials and Methods}

The Central Plantation Crops Research Institute (CPCRI) developed a simple farmer friendly technology for production of vermicompost from the high lignin containing coconut leaves using an indigenous isolate of earthworm Eudrilus sp (Prabhu et al., 1998). The technology became popular and rapidly spread to many of the coconut producing states viz. Karnataka, Tamil Nadu, Andhra Pradesh, Maharashtra, Bihar, Orissa and West Bengal in a span of 10 years. Sale of the nucleus earthworm culture has been good indicator of the percolation of the coconut leaf vermicomposting technology (Gopal et al., 2009).

Further work done at CPCRI led to standardization of vermiwash production as a value addition to coconut leaf vermicompost production technology. Vermiwash production from coconut leaf vermicompost needs the following items -

i) A large plastic drum or earthen pot with a tap fixed at bottom; another small earthen pot to be hung over the drum or bigger pot (Figure 1a and 1b), ii) pre-decomposed substrate i.e. coconut leaves + cowdung at 10:1 ratio w/w basis,

iii) mature coconut leaf vermicompost and

iv) cow dung

v) coconut leaf degrading earthworm (available at CPCRI, Kasaragod)

The drum or big earthen pot is filled with pebbles, then coarse gravel followed by river sand. This set up acts as filtration layer. Water is allowed to flow through this such that the filtration layer settles properly. Above the filtration layer items ii), iii) and iv) are filled at $4: 4: 1$ ratio w/w basis. Water is added to maintain the moisture content at $40 \%$ (ex. 4 litre of water for $10 \mathrm{~kg}$ substrate) followed by addition of the earthworms (5 adult worms for $1 \mathrm{~kg}$ of substrate). The whole unit is kept undisturbed for 10 days allowing the earthworms to feed on the substrates. After $10^{\text {th }}$ day, water is added as trickle from the small pot hung above the drum or bigger pot. After a period of 30 days, the vermiwash that is collected at the bottom of the barrel is drawn from the tap and stored for use. Subsequent collections were made at weekly intervals for a month. The vermiwash thus obtained is clear brown colour liquid (Figure 1c) which is odour free possessing alkaline $\mathrm{pH}$, containing major and minor nutrients, growth hormones, humic acid and plant beneficial bacteria particularly the fluorescent pseudomonads. More detail about the properties of vermiwash and the steps needed for vermiwash production is explained in the article by Gopal and co workers (2010).

To determine the concentration at which the vermiwash should be applied, an in vitro seedling vigour index bioassay at different concentration levels was carried out on cowpea and paddy seeds. Based on the in vitro results, the efficacy of the coconut leaf vermiwash on growth and yield of cowpea, okra and maize was carried out in field studies at CPCRI. Further, to validate the results obtained in the in-house studies, field trials were conducted in collaboration with the Krishi Vigyan KendraKVK (Farm Science Centre), Kasaragod at farmers' plots at Majal and Edneer area in 
Figure 1a. Plastic Drum unit

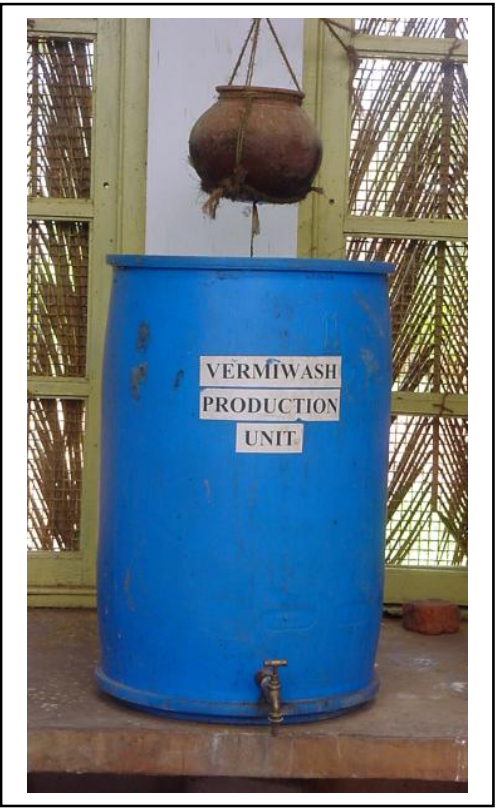

Figure 1b. Earthen pot unit

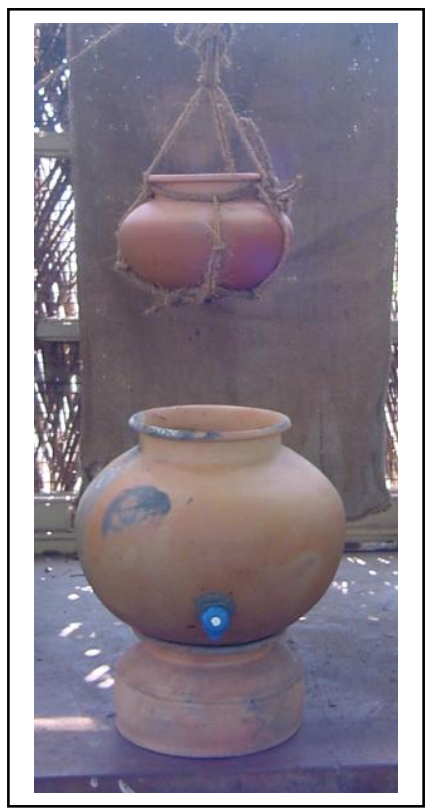

Figure 1c. Coconut leaf vermiwash

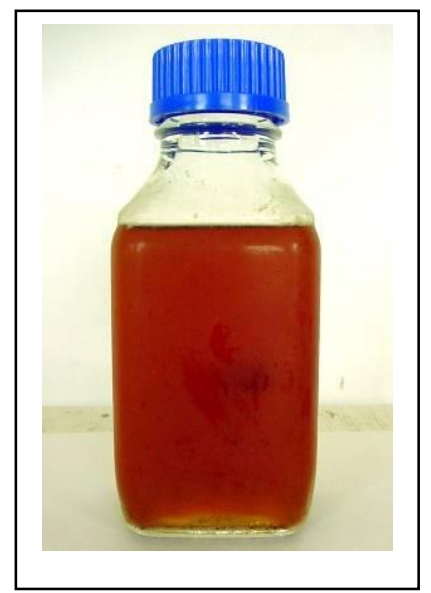

Table 1. Preliminary data of the experiment

\begin{tabular}{|l|l|l|l|}
\hline \multicolumn{1}{|c|}{ Loction of farmers' field } & Name of the farmer & \multicolumn{1}{|c|}{ Soil type } & $\begin{array}{l}\text { Crop raised to evaluate } \\
\text { vermiwash effect }\end{array}$ \\
\hline Majal Panchayath & Mr. Sadanandan & Sandy loam & $\begin{array}{l}\text { Amaranthus, cowpea, } \\
\text { chilli }\end{array}$ \\
\hline Edneer Panchayath & Mr. Ahamed & Laterite soil & Cowpea, bitter gourd \\
\hline
\end{tabular}

Table 2. Effect of coconut leaf vermiwash on fresh biomass yield and nodulation of cowpea

\begin{tabular}{|l|l|l|l|}
\hline \multicolumn{1}{|c|}{ Treatment } & \multicolumn{1}{|c|}{ Fresh biomass (kg) } & \multicolumn{1}{|c|}{$\begin{array}{c}\text { No. of nodules } \\
(\% \text { change })\end{array}$} & \multicolumn{1}{|c|}{$\begin{array}{c}\text { Fresh nodule wt. in g } \\
\text { (\% change) }\end{array}$} \\
\hline Control (water) & 25 & 20 & 24 \\
\hline Vermiwash1:5 & $23(-8 \%)$ & $18(-10 \%)$ & $23.4(-2.5 \%)$ \\
\hline Vermiwash 1:10 & $28(+12 \%)$ & $21(+5 \%)$ & $28.6(+16 \%)$ \\
\hline Vermiwash 1:20 & $34(+36 \%)$ & $26(+30 \%)$ & $34.3(+43 \%)$ \\
\hline
\end{tabular}


Kasaragod District. Two leading farmers, one from Majal and another from Edneer panchayath of Kasaragod District were selected for the field trials (Table 1).

The farmers were supplied with sufficient quantities of coconut leaf vermiwash produced at CPCRI for the validation. They were asked to apply the test plots only with vermiwash diluted with water at 1:5 ratio once in a week followed by regular irrigation with water. The farmers raised the respective crops from seeds obtained from KVK, Kasaragod, Agriculture Department, Kasaragod or the seeds maintained by themselves from their previous harvests. They applied poultry manure + neem cake as basal organic inputs during the preparation of the field followed by inorganic fertilizer mix 17 during the middle stage of crop growth. This was considered as farmers' treatment and it was compared with coconut leaf vermiwash treatment. Irrigation to the crops was done by ground water twice or thrice in a week depending on situation. The farmers allocated 5 rows of amaranthus, cow pea and chillies and 6 pits for bitter gourd for evaluating the effect of coconut leaf vermiwash while the rest of the plots received the inorganic fertilizer treatment. The farmers were asked to record the yield from both the treatments and any other observations they noticed. The rhizosphere soils from the vermiwash treated plots and the farmer's treatment plots were analyzed for soil microbial population and enzyme activities.

\section{Results and Discussion}

Application of appropriately diluted (1:5 to 1:20) coconut leaf vermiwash increased germination and seedling vigour index of cow pea and paddy seeds in laboratory bioassays. Cowpea showed a maximum vigour index of 11.55 at 1:10 dilution, whereas, paddy gave 11.9 at 1:20 dilution. This indicated that appropriately diluted vermiwash had a positive effect on the percentage of seed germination and growth of the cow pea and paddy seedlings. In response to vermiwash application, both crop seedlings produced a profuse growth of fine root hairs, which was absent in the seedlings that received plain water.
Field trials conducted on cowpea, maize and bhendi in Institute farm showed its capacity to enhance the biomass and yield of the crops accompanied by increase in soil microbial populations, enzyme activities and organic carbon content of the soil. For the field experiments, three dilutions of the vermiwash viz. 1:5, 1:10, 1:20 were tried based on the outcome of the laboratory seedling bioassays. It was observed that application of vermiwash enhanced the growth of cowpea at 1:10 and 1:20 dilutions with the latter dilution giving highest percentage of increase in fresh biomass weight $(36 \%)$, higher nodule numbers $(30 \%)$ and nodule fresh weight $(43 \%)$ when compared to control and other vermiwash treatments (Table 2).

In case of maize the total number of cob yield increased with increasing dilution of the vermiwash, however the weight of cobs and fresh biomass weight of the plants were recorded highest (64\% and $30 \%$ above control) at 1: 5 dilution of the vermiwash (Table 3 ).

Similarly an increase in bhendi yield by $33 \%$ over control treatment was also recorded when vermiwash was applied at 1:5 dilution (Table 4). The field studies thus amply supported the fact that application of vermiwash increased the biomass and yield of a range of crops.

Field study with vermiwash on cow pea and maize in CPCRI field

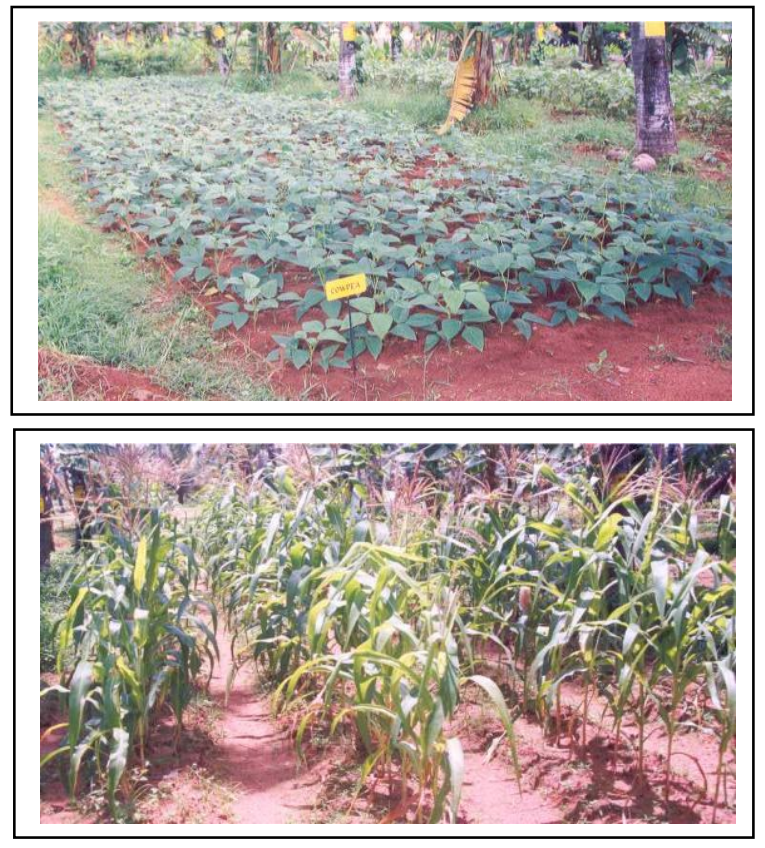


Table 3. Effect of coconut leaf vermiwash on cob yield and fresh biomass of maize

\begin{tabular}{|l|l|l|l|}
\hline \multicolumn{1}{|c|}{ Treatment } & \multicolumn{1}{|c|}{$\begin{array}{c}\text { Cob yield } \\
(\% \text { change })\end{array}$} & \multicolumn{1}{|c|}{$\begin{array}{c}\text { Cob wt. (kg) } \\
(\% \text { change })\end{array}$} & \multicolumn{1}{|c|}{$\begin{array}{c}\text { Fresh biomass (kg) } \\
(\% \text { change })\end{array}$} \\
\hline Control & 42 & 3.1 & 9.07 \\
\hline Vermiwash 1:5 & $44(+5 \%)$ & $5.1(+64 \%)$ & $11.33(+30 \%)$ \\
\hline Vermiwash 1:10 & $45(+7 \%)$ & $4.4(+42 \%)$ & $9.87(+9 \%)$ \\
\hline Vermiwash 1:20 & $46(+10 \%)$ & $4.8(+29 \%)$ & $9.24(+2 \%)$ \\
\hline
\end{tabular}

Table 4. Effect of coconut leaf vermiwash on fruit yield of bhendi

\begin{tabular}{|l|l|}
\hline \multicolumn{1}{|c|}{ Treatment } & \multicolumn{1}{c|}{ Bhendi yield in kg (\% change) } \\
\hline Control & 2.82 \\
\hline Vermiwash 1:5 & $3.76(+33 \%)$ \\
\hline Vermiwash 1:10 & $3.46(+23 \%)$ \\
\hline Vermiwash 1:20 & $3.43(+22 \%)$ \\
\hline
\end{tabular}

Table 5. Yield response of vegetable crops to application of coconut leaf vermiwash and other observations recorded by the farmers. (The results are total yield from 5 rows/pits)

\begin{tabular}{|c|c|c|l|}
\hline Place & Crop & Yield (Kg) & \multicolumn{1}{|c|}{$\begin{array}{c}\text { Farmer's remarks on effect of vermiwash on } \\
\text { growth and yield quality of vegetables }\end{array}$} \\
\hline Majal & Cowpea & $\begin{array}{c}75 \\
(81)^{*}\end{array}$ & $\begin{array}{l}\text { Good quality of produce, better plant growth, } \\
\text { good storage quality of the produce, softer beans }\end{array}$ \\
\cline { 2 - 4 } & Bitter gourd & $\begin{array}{c}200 \\
(218)^{*}\end{array}$ & $\begin{array}{l}\text { Very good quality of produce, healthier look of } \\
\text { the plants, early bearing, delayed ripening of } \\
\text { fruits }\end{array}$ \\
\hline Edneer & Amaranthus & $\begin{array}{c}55 \\
(59)^{*}\end{array}$ & $\begin{array}{l}\text { Bigger leaf size, deep leaf colour, no pest and } \\
\text { disease attack, more hairy roots, harvested plants } \\
\text { showed wilting after longer duration }\end{array}$ \\
\cline { 2 - 5 } & Cowpea & $\begin{array}{c}155 \\
(156)^{*}\end{array}$ & $\begin{array}{l}\text { Better plant growth, produce was of good quality } \\
\text { and more tastier }\end{array}$ \\
\cline { 2 - 5 } & Chilli & $\begin{array}{l}10 \\
(12)^{*}\end{array}$ & $\begin{array}{l}\text { Rich green colour of the leaves, better plant } \\
\text { growth, good pungency }\end{array}$ \\
\hline
\end{tabular}

* Yield from plots receiving farmers' inputs of poultry manure+neem cake as basal application followed by inorganic fertilizer mix 
Luxuriant growth and good bearing of bitter gourd at farmer's field in Majal (a) chilli (b) and cowpea (c) at Edneer

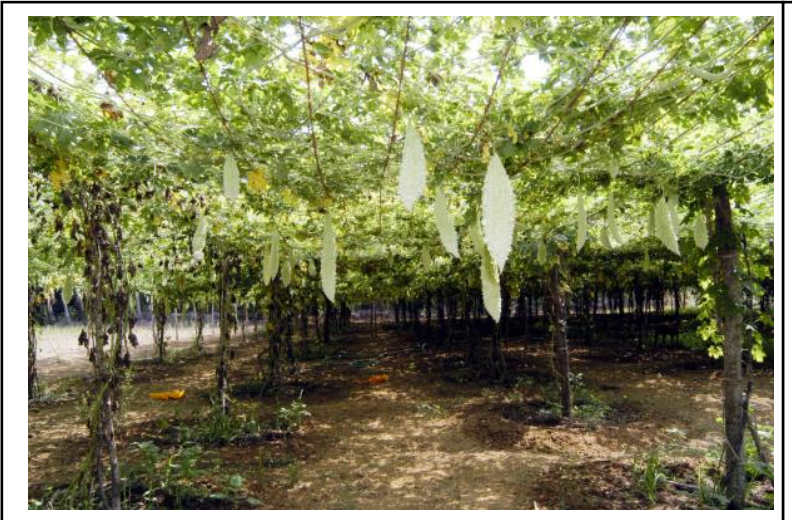

(a)

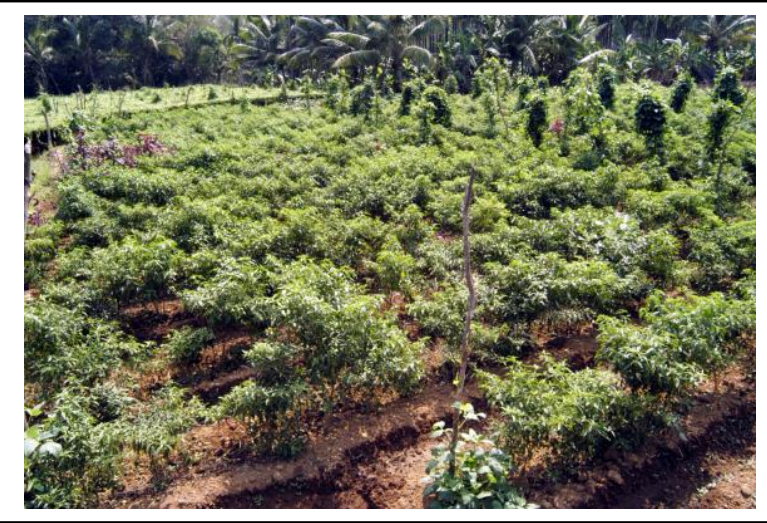

(b)

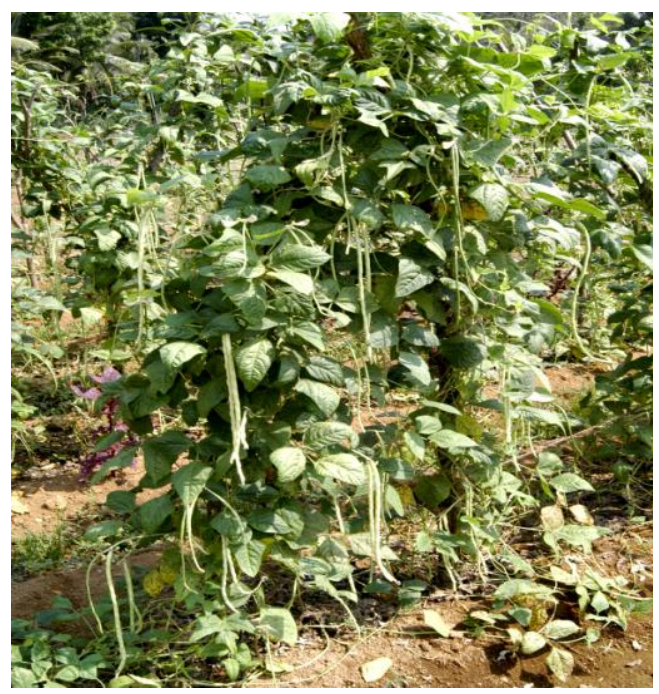

(c)

Lush growth of amaranthus with profuse production of fine root hairs in the vermiwash treated plots at Edneer

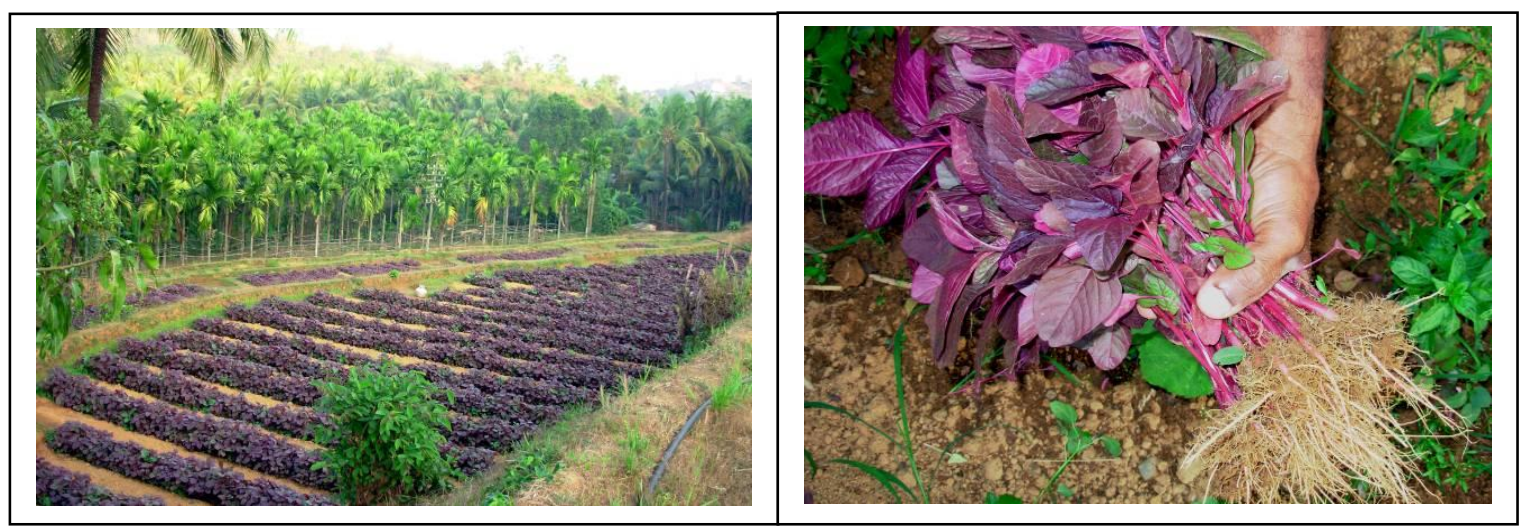


Vermiwash application yielded 75 and 200 $\mathrm{kg}$ cow pea and bitter gourd respectively at farm in Majal and 55, 155 and $10 \mathrm{~kg}$ of amaranthus, cowpea and chillies, respectively, at Edneer farm (Table 5). It is clearly seen that the application of vermiwash produced yields on par or slightly less compared to plots receiving farmers' regular inputs of organic and inorganic fertilizers. Agronomic performance of organic systems elsewhere have reported reduction in crop yields by up to $20 \%$ with concomitant reduction in fertilizer and energy inputs by $34-53 \%$ and pesticide input by $97 \%$. However, the farmers opined unanimously that application of coconut leaf vermiwash helped in production of better quality vegetables. They reported that application of vermiwash produced amaranthus possessing dense root hairs, broad and tender leaves with deep colour and minimum pest and disease incidence (Table 5). The crop stand of bitter gourd, cowpea and chilli was also very lush.

Studies on soil microflora and enzyme activity measurements have been used as indicators of soil functionality and thus, indicators of soil. It was observed that application of coconut leaf vermiwash stimulated the population of all the soil microbial communities, particularly the plant beneficial group of free living nitrogen fixers, phosphate solubilizers and fluorescent pseudomonads, which form an important fraction of the plant growth promoting rhizobacteria. Similarly, the activities of three important soil enzymes viz. dehydrogenase, phosphatase and uerease increased sharply in the vermiwash applied plots compared to the poultry manure + neem cake and inorganic fertilizer applied plots ( Figure $2 \mathrm{a}$ and $2 b$ ).

Coconut leaf vermiwash has also been reported to have a deleterious effect on the juveniles of burrowing nematode, Radopholus similis, root-knot nematode, Meloidogyne incognita, root lesion nematode, Pratylenchus coffeae and spiral nematode, Helicotylenchus multicinctus which are some of the major nematode pests of crops in coconut based highdensity multi-species cropping system (Banu and Iyer et al., 2006). Vermicompost and liquid vermiwash produced from other crop residues have also been found to be effective as an organic source of fertilizer comparable with inorganic source of fertilizer and biological disease prevention in a number of vegetable crops.

Thus we observed in vermiwash treated plots a clear correlation between increases in microbial population with increased enzyme activities as much of the soil enzymes originate from microbial biomass. This clearly indicated that vermiwash had a positive influence in building up the soil quality and health when compared to farmers' inputs, which must have resulted in production of quality vegetables (Gopal et al 2010). Improvement in soil fertility and biodiversity in organic farming has been well documented by many workers.

\section{Conclusions}

Application of coconut leaf vermiwash as soil drenching was able to boost the biomass yield and nodule numbers of cow pea, cob and fruit yields of maize and bhendi in the trials conducted at CPCRI. However, in validation trial conducted in farmers' plots, the yield of cowpea, amaranthus, chilli and bitter gourd was on par or slightly less compared to farmers' regular inputs of organic and inorganic fertilizers. But the produce from vermiwash applied plot was of superior quality as opined by the farmers themselves. In addition to this, the application of vermiwash increased the soil microbial populations, particularly the plant beneficial ones along with the increase in soil enzyme activities. The mode of action was primarily due to improvement of the crop production capacities of the soil through i) enhanced organic $\mathrm{C}$ content of the soils ii) increase in the microbial numbers, particularly the beneficial ones as well as key soil enzyme activities in the root region of the crops and iii) direct effect of plant growth promoting substances and nutrients present in vermiwash. Thus, use of coconut leaf vermiwash can improve soil quality and fertility and production of quality vegetables. However, proper dilution of vermiwash is important for getting desirable results. For vegetative growth, vermiwash at 
Figure 2. Effect of application of coconut leaf vermiwash on microbial population (2a) and enzyme activities (2b) in rhizosphere soils of different vegetables

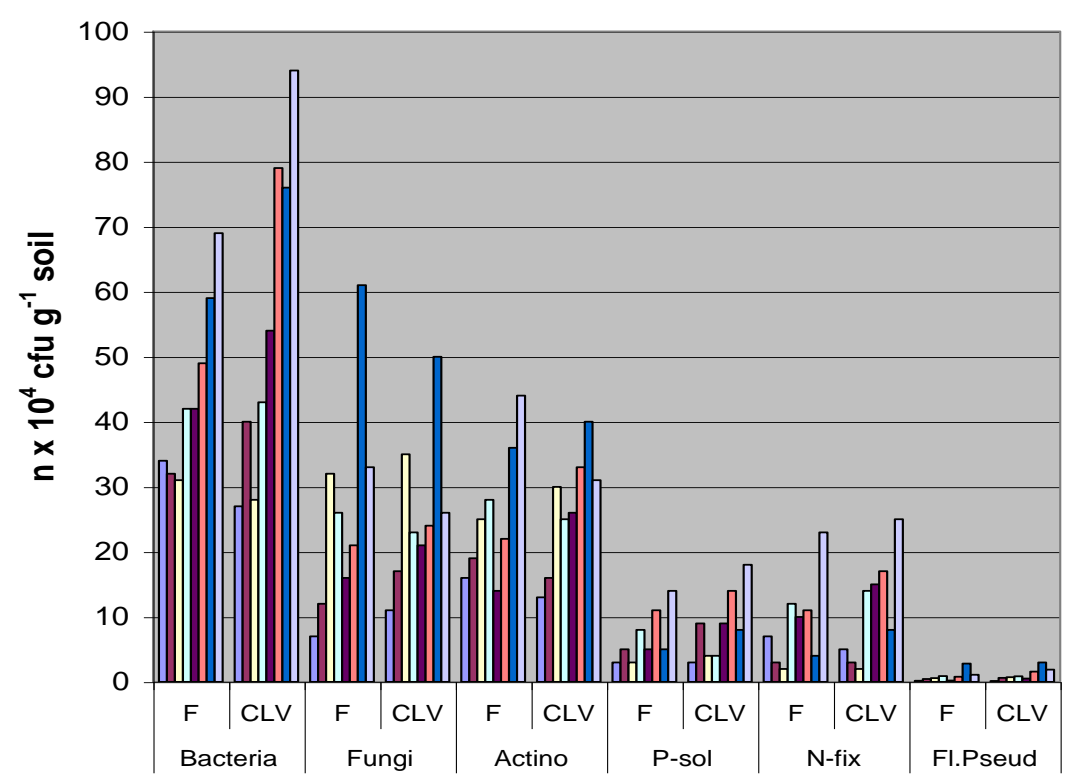

$\square$ Amaranthus-Edneer Pre-treat

$\square$ Cowpea-Edneer Pre-treat

$\square$ Chilli-Edneer Pre-treat

$\square$ BitterGourd-Majal Pre-treat

- Amaranthus-Edneer Post-treat

$\square$ Cowpea-Edneer Post-treat

$\square$ Chilli-Edneer Post-treat

$\square$ BitterGourd-Majal Post-treat

Microbial communities and treatments

Figure 2a

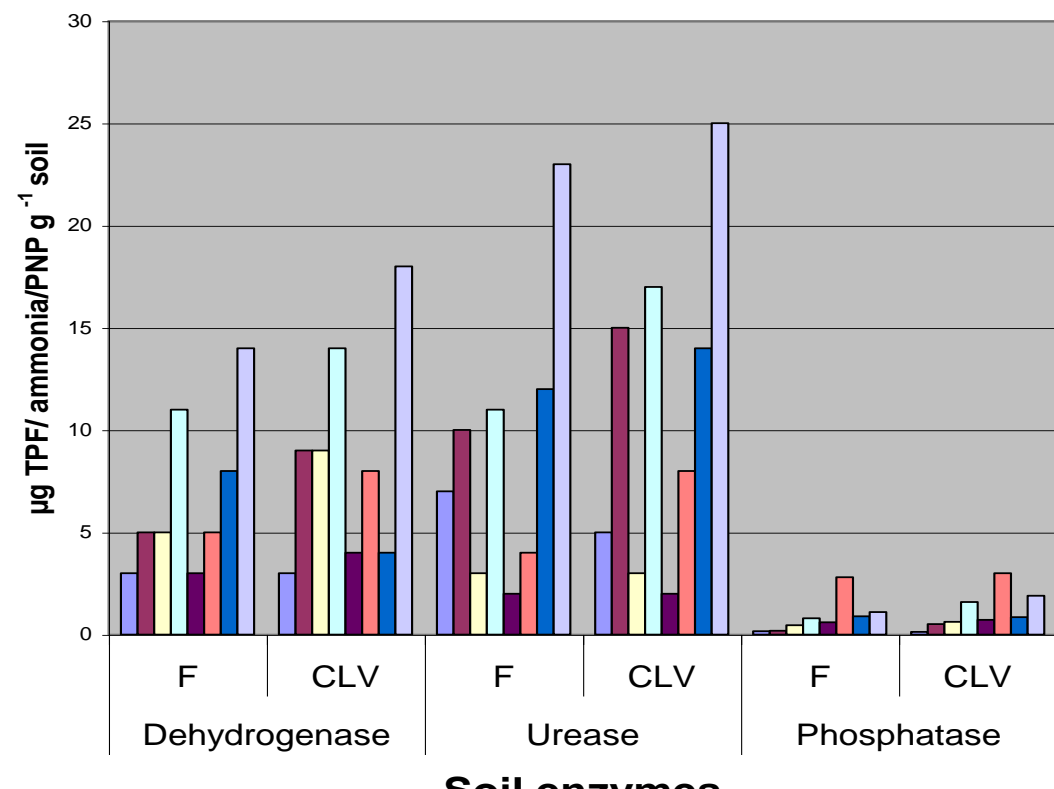

$\square$ Amaranthus-Edneer Pre-treat amaranthus-Edneer Post-treat $\square$ Cowpea-Edneer Pre-treat $\square$ Cowpea-Edneer Post-treat - Chilli-Edneer Pre-treat $\square$ Chilli-Edneer Post-treat $\square$ BitterGourd-Majal Pre-treat $\square$ BitterGourd-Majal Post-treat

Figure 2b 
1:10 dilution and for economic yield output like fruits and cobs, 1:5 dilution was observed to be appropriate. It must also be noted that the positive effect of application of vermiwash alone as fertilizer by itself cannot be sustainable as it has low concentrations of major and minor nutrients. It needs to be combined with other organic manure addition to make it more effective, particularly when used for plantation crops.

The experience thus points to the fact that coconut leaf vermiwash can be used as one of the eco-friendly components of organic farming input for sustainable soil health and fertility.

\section{Acknowledgement}

The authors thank the reviewer of this article for the critical comments that has helped in improving the ms.

\section{References}

Banu, J.G. and Iyer, R. 2006. Effect of Vermiwash on Nematodes Prevalent in Coconut Based High-Density Multispecies Cropping System. Indian Journal of Nematology 36(2): 176-180.

Gopal, M., Gupta, A., and Thomas, G.V. 2009. Importance of producing nucleus earthworm culture for the dissemination and popularization of coconut leaf vermicomposting technology. Indian Coconut Journal. 51 (10): 8-12

Gopal, M., Gupta, A., Palaniswami, C., Dhanapal, R and Thomas, G.V 2010. Coconut leaf vermiwash: a novel bioliquid from coconut leaf vermicompost for improving the crop production capacities of soil. Current Science 98:1202-1210

Gopal, M., Gupta, A., Rayudu, B.T. and Thomas, G.V. 2010. Coconut leaf vermiwash for soil health improvement and Quality yield of vegetable crops Validation in farmers' fields. In Singh, H.P. and Thomas, G.V, Organic Horticulture: Principles, Practices and
Technologies (eds). Westwille Publishing House, New Delhi, India, pp 223-229.

Ismail, S.A. 1997. Vermicology - the biology of earthworms. Orient Longman, India, pp. 192.

Kale, K.E. 1988. Earthworm: Cinderella of organic farming. Bangalore: Prism Books Pvt. Ltd. India. pp-88.

Prabhu, S.R., Subramanian, P., Bidappa, C.C. and Bopaiah, B.M., 1998. Prospects of improving coconut productivity through vermiculture technologies. Indian Coconut Journal 29, 79 - 84 